\title{
Upaya Guru PPKn Dalam Proses Remedial di Bawah Kriteria Ketuntasan Minimal Kelas VIII SMP Negeri 3 Dompu
}

\author{
Ditha Anggraini ${ }^{1}$, Hafsah²
}

${ }^{1}$ Pendidikan Pancasila dan Kewarganegaraan, Universitas Muhammadiyah Mataram, ditha.anggraini18@gmail.com

${ }^{2}$ Pendidikan Pancasila dan Kewarganegaraan, Universitas Muhammadiyah Mataram, dansa.manchi@yahoo.co.id

INFO ARTIKEL
Riwayat Artikel:
Diterima: $\quad 10$-Agustus-
2018
Disetujui: 12-September-
2018

\section{Kata Kunci:}

upaya

guru

remedial

\section{A. LATAR BELAKANG}

Pendidikan sangat penting untuk kelangsungan hidup manusia, dengan pendidikan seorang manusia mampu mendapatkan posisinya dalam masyarakat dan meningkatkan derajatnya untuk kesejahteraan hidupnya. dalam proses pendidikan di sekolah, proses belajar mengajar merupakan kegiatan inti. Lembaga pendidikan baik sekolahsekolah maupun Perguruan Tinggi sangat

\begin{abstract}
Abstrak: Remidial merupakan suatu bentuk pengajaran yang bersifat menyembuhkan atau membetulkan, atau pengajaran yang membuat menjadi baik. Saat ini sebagaian siswa yang belum mencapai kriterial ketuntasan minimal sehingga perlu dilakukan perbaikan. Tujuan penelitian ini adalah untuk menjelaskan upaya guru PPKn dalam melakukan proses remedial siswa dan faktor apa yang mempengaruhi upaya guru PPKn dalam melakukan remedial untuk mencapai KKM kelas VIIIB SMP Negeri 3 Dompu. Jenis penelitin menggunakan penelitian kualitatif dengan pendekatan deskriptif. Pengumpulan data yang pakai yakni observasi, wawancara, dan dokumentasi. Subyek penelitian adalah guru dan siswa. Peneliti menggunakan triangulasi teknik untuk memperoleh keabsahan data.Teknik analisis data yang digunakan adalah reduksi data, penyajian data, verifikasi dan menarik kesimpulan. Hasil penelitian mengambarkan bahwa dalam proses remedial guru melakukan upaya-upaya yang di berikan kepada siswa yang mendapatkan nilai di bawah KKM, upaya yang dilakukan oleh guru seperti memberikan motivasi, membimbing siswa, memberikan umpan balik, dan memberikan perhatian yang lebih. Faktor yang mempengaruhi upaya guru dalam proses remedial yaitu faktor internal dan faktor eksternal. Faktor internal terdiri dari siswa yang tidak mau mengikuti remedial dan kurangnya kesiapan guru di dalam terlaksananya remedial. Faktor eksernal ada di dalam keluarga dan lingkungan, adanya faktor-faktor tersebut dapat mempengaruhi perkembangan siswa dan dapat mempengaruhi minat belajar siswa.
\end{abstract}

Abstract: Remidial is a form of teaching that is healing or correct, or teaching that makes it good. At present some students who have not achieved the minimum completeness criteria need improvement. The purpose of this study was to explain the efforts of PPKn teachers in conducting student remedial processes and what factors influenced the efforts of PPKn teachers in conducting remedials to reach class VIIIB KKM in Dompu 3 Public Middle School. This type of research uses qualitative research with a descriptive approach. Data collection used is observation, interviews, and documentation. The research subjects were teachers and students. The researcher used triangulation techniques to obtain the validity of the data. Data analysis techniques used were data reduction, data presentation, verification and drawing conclusions. The results of the study illustrate that in the remedial process the teacher makes efforts that are given to students who get grades under the KKM, the efforts made by the teacher such as giving motivation, guiding students, giving feedback, and giving more attention. Factors that influence teacher efforts in remedial processes are internal factors and external factors. Internal factors consist of students who do not want to follow remedial and lack of teacher readiness in the implementation of remedial. External factors exist in the family and the environment, the existence of these factors can influence the development of students and can affect students' learning interest. menentukan masa depan bangsa ini, lembagalembaga ini sebagai wadah yang akan membentuk anak bangsa, dibangun dari teori-teori dan praktik lapangan secara akademik yang dipersiapkan secara langsung untuk berada di lapangan atau dunia sosial[1].

Pembelajaran merupakan inti dan muara segenap proses pengelolaan pendidikan[2]. Melalui proses belajar akan dicapai tujuan instruksional pendidikan dalam bentuk perubahan tingkah laku 
belajar agar memperoleh ketuntasan dalam belajar karena belajar tuntas sangat penting dalam mencapai hasil belajar yang baik. Dalam hal ini dijelaskan tentang proses pelaksanaan program remidial di SMP Negeri 3 Dompu, dimana salah satu tujuannya adalah untuk mengetahui apakah pelaksanaannya sesuai dengan prosedur pelaksanaan remidial yang telah ditetapkan atau belum. Strategi atau langkah-langkah yang digunakan oleh guru mata pelajaran PPKn dalam melaksanakan remidial, terutama dalam upaya untuk meningkatkan ketuntasan belajar siswa di sekolah tersebut.

Belajar mengajar adalah suatu kegiatan yang bernilai edukatif, nilai edukatif mewarnai interaksi yang terjadi antara guru dengan siswa. Interaksi yang bernilai edukatif dikarenakan kegiatan belajar mengajar yang dilakukan, diarahkan untuk mencapai tujuan tertentu yang telah dirumuskan sebelum pengajaran dilakukan. Guru dengan sadar merencanakan kegiatan pengajarannya secara sistematis dengan memanfaatkan segala sesuatu guna kepentingan pengajaran.

Dengan demikian siswa mampu mencapai hasil belajar dengan sebaik-baiknya untuk mencapai suatu ketuntasan belajar. Pada dasarnya setiap siswa dapat dibantu baik secara individual maupun kelompok untuk memperbaiki hasil belajar yang dicapainya sesuai dengan kemampuannya masingmasing. Bantuan yang dapat dilaksanakan adalah remidial, yaitu suatu bentuk pengajaran khusus yang sifatnya memperbaiki proses belajar. Remidial digunakan untuk membantu siswa yang mengalami kesulitan belajar. Setiap guru seharusnya mempunyai pengetahuan tentang remidial dan dapat melaksanakannya dalam keseluruhan kegiatan belajar-mengajar, remedial dilaksanakan di seluruh sekolah baik itu dari jenjang SD, SMP, dan SMA. Kebanyakan letak kesulitan belajar siswa adalah pada tahap memahami (comprehension) dan tranformasi[3].

Berdasarkan hasil observasi awal yang dilaksanakan pada tanggal o6 Desember 2017 di SMP Negeri 3 Dompu bahwa masih banyak siswa yang belum mencapai KKM khususnya kelas VIIIB, dan guru mengupayakan untuk melakukan remedial kepada siswa yang mendapatkan nilai di bawah KKM. Guru memberikan nilai standar KKM adalah 70, Dari 30 siswa kelas VIIIB yang melakukan ulangan akhir semester dengan mengisi 25 Nomor ulangan akhir semester, siswa yang sudah mencapai KKM sebanyak 18 orang dan yang belum mencapai KKM sebanyak 12 orang, siswa yang mendapatkan dibawa KKM sebanyak 11 orang, guru mengupayakan untuk melakukan remedial supaya siswa dapat mencapai KKM dan guru mampu memberikan motivasi belajar siswa, guru juga mampu memberikan bunyi soal yang mudah dipahami oleh siswa, dengan demikian siswa yang belum mampu mencapai standar kompetensi guru yang mampu berperan aktif memberikan dorongan kepada siswa, data ini didapatkan dari Guru PPKn yang mengajar di sekolah SMP Negeri 3 Dompu dari hasil nilai kelas VIIIB SMP Negeri 3 Dompu.

Jika dilihat dari nilai yang ada, kenyataan ini akan menjadi semakin serius apabila tidak segera diatasi. Salah satu kegiatan yang dapat digunakan untuk mengatasi masalah tersebut adalah dengan melaksanakan program remedial. program remedial berpengaruh positif terhadap hasil belajar siswa. Artinya hasil belajar sesudah remedial lebih tinggi dari hasil belajar sebelum remedial dilakukan. Dengan demikian program remedial dapat menolong siswa yang mengalami kesulitan belajar untuk mencapai ketuntasan belajar[4].

Dengan KKM, siswa yang telah berhasil dapat melanjutkan belajar untuk dapat menguasai kompetensi selanjutnya, dan yang belum menguasai dapat memperdalam yang belum dikuasai melalui remidi[5]. Pembelajaran remedial pada mata pelajaran PKn siswa SMP guru memberikan kesempatan kepada seluruh peserta didik untuk mencapai dan menguasai kompetensi sesuai dengan kemampuannya masing-masing yang menjadi motivasi bagi siswa dalam Proses penerapan pembelajaran remedial dan siswa menyatakan sangat membantu menuntaskan pencapaian belajar pada mata pelajaran PKn sesuai nilai SKBM 70 yang berlaku di SMP. Hal ini terlihat dari peran guru PKn selama dalam pembelajaran remedial berupaya membina dan mengenbangkan sikap siswa melalui pengawasan, penjelasan kembali materi pelajaran PKn dan memberi pengulangan kembali sampai nilai siswa mencapai nilai Standar Ketuntasan Belajar Minimal yang ada di sekolah[6].

\section{B. METODE PENELITIAN}

1. Metode yang Digunakan

Penelitian ini menggunakan metode penelitian kualitatif dengan pendekatan deskriptif. metode "penelitian kualitatif adalah penelitian yang 
digunakan untuk peneliti pada kondisi obyek yang alamiah[7]. Sedangkan pendekatan dekripktif digunakan untuk berupaya memecahkan atau jawaban atau permasalahn yang sedang dihadapi pada situasi sekarang. Dilakukan dengan menempuh langkah-langkah pengumpulan, klasifikasi, dan analisis dan pengolahan data, membuat kesimpulan dan laporan dengan tujuan utama untuk membuat gambaran tentang sesuatu keadaan secara objektif dalam suatu dekriptif situasi. Itulah sebabnya disebut dengan pendekatan deskriptif "[8].

Penggunaan penelitian kualitatif dengan pendekatan deskriptif dikarena permasalah belum jelas di dalam penelitian ini harus mendapatkan data yang sebenarnya terjadi sebagaimana adanya, penelitian ini tidak terpandu oleh teori tetapi oleh fakta-fakta yang ditemukan pada sa,at penelitian di lapangan, teknik pengumpulan data ini melalui observasi, wawancara, dan dokumentasi. Peneliti dapat menggunakan pendekatan deskriptif yang dimana situasi harus dihadapi di dalam lapangan harus melalui langkah-langkah pengumpulan data ini untuk memecahkan permasalah atau memberikan menjawab dari rumusan masalah.

2. Subyek Penelitian

Subjek penelitian merupakan pihakpihak yang menjadi sasaran peneliti. Guru dan siswa sebagai subjek penelitian dikarenakan guru sangat penting dalam mengatur proses remedial dan siswa sebagai subjek ke dua dari penelitian yang dapat memberikan informasi tentang remedial.

3. Metode Pengumpulan Data

Teknik atau cara yang dilakukan untuk mengumpulkan data .metode menunjukan suatu cara sehinggah dapat memperlihatkan penggunaannya melaui observasi,wawancara dan dokumentasi.

a. Observasi

Observasi adalah dasar semua ilmu pengetahuan[9]:[7]. Para ilmuan hanya dapat bekerja berdasarkan data. Yaitu fakta mengenai dunia kenyataan yang diperoleh melalui observasi.

Metode observasi dalam penelitian ini dapat melihat guru dengan efektif meningkatkan proses remedial untuk mencapai KKM yang telah ditetapkan khususnya kelas VIIIB SMP Negeri 3 Dompu, yang diobsevasi adalah guru dengan siswa sa'at melaksanakan remedial.

b. Wawancara
Wawancara merupakan salah satu teknik pengumpulan data yang dilakukan dengan cara mengadakan tanya jawab, baik secara tidak langsung maupun langsung secara bertatap muka (personal face to face interview) dengan sumber data (responden)[10]. Pendapat lain menjelaskan wawancara merupakan pertemuan dua orang yang bertukar informasi dan ide melalui tanya jawab, sehingga dapat dikonstruksikan makna dalam suatu topik tertentu[11].

Metode wawancara digunakan untuk mendapatkan data tentang proses remedial. Dengan menggunakan wawancara tidak terstruktur, peneliti harus membawa instrumen sebagai pedoman untuk wawancara, maka penggumpulan data juga dapat menggunakan alat bantu seperti gambar, tape recorde, brosur material yang dapat membantu pelaksanaan wawancara menjadi lancar.

c. Dokumentasi

Dokumentasi merupakan suatu penggumpulan data dengan mencatat data-data yang berkaitan dengan proses remedial. Sedangkan "dokumentasi merupakan peristiwa yang sudah berlalu. dokumentasi bisa berbentuk tulisan, gambar atau karya-karya dari seseorang"[7].

Dalam penelitian ini metode dokumentasi yang digunakan oleh peneliti untuk memperoleh data penelitian yaitu nilai remedial, data tentang remedial, gambar saat proses remedial, dan datadata yang di perlukan mengenai proses remedial.

4. Tehnik Analisi Data

Setelah data selesai dikumpulkan dengan lengkap dari lapangan tahap berikutnya adalah tahap analisis. Pada tahap ini data dikerjakan dan dimanfaatkan sedemikian rupa sehingga dapat menyimpulkan kebenaran-kebenaran yang dapat dipakai untuk menjawab persoalan-persoalan yang di ajukan dalam penelitian[12].

Dengan proses analisis data dalam penelitian kualitatif dan peneliti menggunakan teknik diskriptif, Ada tiga alur kegiatan yaitu sebagai berikut[13];[7]:

1. Reduksi data adalah proses pemilihan, pemusatan perhatian pada penyederhanaan, pengabstrasiksian dan transpormasi data kasar dari catatan tulisan selama di lapangan. Untuk mereduksi data peneliti membuat ringkasan kontak, mengembangkan kategori, pengkodean dan membuat catatan refleks yang bermaksud menajamkan, penggolongan, mengarahkan yang tidak berlaku. Kemudian mengorganisasikan 
sedemikian rupa sehingga kesimpula yang tepat, ini dilakukan secara terus-menerus selama penelitian berlangsung.

2. Penyajian data adalah merupakan sekumpulan informasi tersusun yang memberikan kemungkinan adanya penarikan kesimpulan dan penarikan tindakan. Data teks naratif penelitian dijadikan dalam bentuk metrik, diagram, jaringan, dan tabel yang dirancang peneliti untuk menggabungkan informasi dan diinformasikan dalam bentuk sederhana dan bentuk terpadu, sehingga dapat melihat apa yang sedang terjadi.

3. Kesimpulan verivikasi adalah upaya yang diperoleh selama penggumpulan data berlangsung. Penulis melakukan kesimpulan sejak awal pengumpulan data. Kesimpulan yang kurang jelas meningkatkan semakin rinci dan menyusun laporan final selesai. Untuk kesimpulan final peneliti terus mengadakan pengujian (verivikasi) selama peneliti berlangsung dengan berbagai cara antara lain meninjau catatan di lapangan.

\section{HASIL DAN PEMBAHASAN}

\section{Upaya Guru PPKn Dalam Melakukan Proses Remedial Siswa Kelas VIII B SMP Negeri 3 Dompu}

Survai awal adalah merupakan studi pendahuluan yang dilakukan untuk mengetahui bagaimana upaya guru dalam melakukan proses remedial yang di berikan kepada siswa yang belum mencapai KKM. Dalam survai awal ini data dikumpulkan melalui observasi, wawancara dan dokumentasi .

Hasil observasi, wawancara dan dokumentasi bahwa Proses remedial dilaksanakan pada hari rabu tanggal 14/03/2018 tepatnya di kelas VIII B, proses remedial ini diberikan untuk siswa yang belum mencapai KKM, yang di tetapkan oleh guru standar KKM adalah 75 sedangkan siswa yang melaksanakan remedial sebanyak 16 orang dari 30 siswa. remedial ini dilaksanakan 1 minggu sesudah ulangan tengah semester dengan instrumen soal 5 nomor, guru memberikan bimbingan kepada siswa sebelum dilaksanakan remedial, dengan adanya remedial guru berusaha mengurangi siswa yang mendapatkan nilai di bawah KKM.

Banyak upaya-upaya yang dilakukan oleh guru untuk mengurangi siswa yang mendapatkan nilai di bawah KKM seperti pada umumnya peneliti dapat melihat dari hasil wawancara dan observasi bahwa pada kenyataanya upaya guru untuk mengurangi jumlah siswa yang mendapatkan nilai di bawah KKM sangat baik. yang memberikan informasi saat penelitia mengenai remedial adalah bapak irwan ( salah satu guru PPKn di SMP Negeri 3 Dompu )
Peneliti melakukan wawancara dengan guru mengenai upaya-upaya yang dilakukan dalam melaksanakan proses remedial setiap selesai ulangan baik itu ulangan harian, UTS, dan UAS. Disimak melalui kutipan hasil wawancara dengan guru pada hari kamis 14/03/2018 sebagai berikut.

"Upaya yang saya lakukan selaku guru PPKn kelas VIII B dalam melaksanakan proses remedial untuk mencapai KKM yaitu dengan memberikan motivasi, membimbing, memberikan pujian, dan perhatian yang lebih kepada siswa supaya saat remedial siswa mampu mencapai KKM yang di tetapkan oleh guru, dan dengan demikian siswa dapat menggurangi yang mendapatkan di bawah KKM, dalam remedial saya berusaha supaya siswa mampu mengerjakan instrumen soal saat melaksanakan remedial, dan dilakukan evaluasi kembali"

Hasil wawancara dengan dengan narasumber bahwa guru melakukan upaya-upaya mampu mengurangi siswa yang mendapatkan nilai di bawah KKM, upaya yang dilakukan oleh guru adalah dengan tujuan membangun siswa untuk memiliki prestasi belajar,selain wawancara dapat di perkuat dengan hasil observasi bahwa peneliti melakukan observasi banyak upaya-upaya yang dilakukan oleh guru untuk mengurangi siswa yang belum mencapai KKM.

Pelaksanaan beberapa upaya yang dilakukan oleh guru untuk bertanggung jawab dan melaksanakan semua tindakan tersebut di kelas VIII B mampu mengurangi siswa yang mendapatkan nilai di bawah KKM dengan memberikan motivasi, membimbing, memberikan umpan balik, dan perhatian yang lebih kepada siswa supaya saat remedial siswa mampu mencapai KKM yang ditetapkan oleh guru.

Bukan hanya melakukan wawancara dengan guru, peneliti juga melakukan wawancara dengan siswa kelas VIII B SMP Negeri 3 Dompu. Upaya guru dalam melaksanakan remedial untuk mencapai KKM beberapa siswa yang diwawancara oleh peneliti pada hari kamis 15/03/2018 adalah sebagai berikut.

\section{"Siswa yang bernama Al-Amin} mengungkapkan tentang upaya guru PPKn dalam proses remedia, bahwah upaya guru sangat baik dalam melaksanakan proses remedial tapi kita sebagai siswa kurang aktif belajar dan siswa yang bernama Yanti mengungkapkan bahwah dalam proses remedial guru memberikan motivasi dan dengan upaya guru yang sangat strategi untuk memberikan kisi-kisi soal supaya remedial berjalan dengan lancar ungkapan M.Toha saya adalah salah satu siswa yang mendapatkan nilai di bawah KKM karna 
saya sendiri kurang minat belajar dan saat ulangan kurang memahami soal dalam ungkapan Emawati bahwa kami kurang belajar namun guru selalu memotivasi dan mendorong kami supaya mampu mencapai KKM setiap melaksanakan ulangan"

Beberapa ungkapan siswa di atas bahwa upaya guru SMP Negeri 3 Dompu sudah sangat baik meskipun masih memiliki beberapa faktor. Guru akan selalu berusaha untuk bagaimana meningkatkan nilai dan membangun motivasi belajar siswa yang mendapatkan di bawah KKM, guru berusaha untuk menciptakan anak bangsa yang cerdas.

Upaya-upaya yang dilakukan oleh guru dalam proses remedial untuk mencapai KKM kelas VIII B SMP Negeri 3 Dompu adalah sebagai berikut:

a. Motivasi

Motivasi sangat penting dalam proses remedial untuk membangun semangat siswa yang mendapatkan nilai di bawah KKM, berjalannya proses remedial guru memberikan motivasi supaya semangat belajarnya semakin meningkat untuk kedepannya.

Guru sangat berperang penting dalam perkembangan dalam lingkungan sekolah terutama untuk membangun motivasi belajar siswa yang tidak semangat belajar, adanya siswa yang mendapatkan dibawah KKM karna siswa yang semangat belajarnya berkurang.

Peneliti melakukan wawancara di lapangan bahwa guru memberikan motivasi kepada siswa dalam proses remedial untuk mencapai nilai di bawah KKM, dapat disimak dari ungkapan guru pada hari rabu 21/03/2018 adalah sebagai berikut.

"Motivasi yang saya berikan kepada siswa adalah salah satu upaya yang saya lakukan untuk membangun minat belajar siswa yang mendapatkan nilai di bawah KKM, saya selalu berupaya untuk memberikan motivasi kepada siswa dan saat pada proses remedial"

Ungkapan di atas mengambarkan bahwa guru memberikan motivasi kepada siswa untuk membangun semangat dan minat belajar di dalam lingkungan sekolah dan bukan hanya motivasi saja upaya yang dulakukan oleh guru melainkan dengan melakukan umpan balik.

Motivasi yang diberikan oleh guru kepada siswa sangat baik, selain melakukan wawancara dapat di perkuat dengan observasi lapangan bahwa banyak kata-kata motivasi yang diberikan oleh guru kepada siswa, dengan memberikan motivasi siswa dapat membangun minat belajarnya supaya mampu mencapai KKM.

b. Membimbing Siswa

Siswa yang belum mencapai KKM selain memberikan motivasi guru juga membimbing khusus kepada siswa yang belum mencapai KKM, guru memberikan bimbingan sebelum terjadinya proses remedial, dalam proses remedial guru melakukan upaya untuk mencapai keberhasilan siswa.

Guru memberikan bimbingan kepada siswa yang belum memahami soal dan kurangnya motivasi belajar, dengan adanya bimbingan siswa dapat mencapai KKM yang ditetapkan oleh guru dan motivasi adalah hal yang paling utama dalam dunia pendidikan.

Peneliti melakukan wawancara di lapangan dengan guru mengenai bimbingan yang dilakukan sebelum proses remedial untuk mencapai KKM pada hari rabu 21/03/2018 adalah sebagai berikut.

"siswa yang belum mencapai KKM masih banyak, dengan demikian saya memberikan bimbingan terlebih dahuluh sebelum malaksanakan proses remedial dengan adanya bimbingan disertai dengan motivasi siswa mampu mencapai KKM yang ditetapkan"

Hasil wawancara dengan guru di atas bahwa sebelum melakukan proses remedial harus adanya bimbingan terlebih dahulu supaya siswa mampu mencapai KKM yang ditepkan oleh guru, bahwa bimbingan itu perlu dilakukan kepada siswa yang belum mencapai KKM. selain wawancara dapat di perkuat dengan hasil observasi bahwa peneliti melakukan observasi lapangan guru memberikan bimbingan kepada siswa yang belum mencapai KKM.

c. Memberi Umpan Balik

Guru sangat berperang penting dalam perkembangan siswa yang belum mencapai KKM, dengan demikian dalam proses remedial guru membangun semangat siswa dalam melaksanakan proses remedial dengan memberikan umpan balik saat pembelajaran dilakukan

Siswa akan meningkat motivasi belajarnya walaupun belum mencapai KKM dan guru memberikan umpan balik kepada siswa dengan kata-kata motivasi supaya untuk meningkatkan minat belajarnya yang sangat maju, siswa juga akan mampu mencapai KKM yang telah di tetapkan .

Peneliti melakukan wawancara dengan guru bahwa pemberian umpan balik kepada siswa saat proses pembelajaran supaya dapat mencapai KKM yang ditetapkan dapat disimpak dari ungkapan guru pada hari rabu 28/03/2018 adalah sebagai berikut:

"Saya sebagai guru akan selalu
memberikan pujian kepada siswa supaya
semangat belajarnya semakin meningkat
dengan begitu siswa akan mendapatkan
nilai di atas KKM yang telah di tentukan
walaupun sebagian siswa yang belum
mencapai KKM"

Hasil wawancara di atas mengambarkan bahwa memberian umpan balik adalah sala satu upaya yang dilakukan oleh guru saat proses pembelajaran berjalan supaya siswa mampu mencapai KKM yang ditetapan oleh guru, dengan memberikan umpan 
balik kepada siswa semangat belajar akan tinggi terutama kepada siswa yang mendapatkan nilai di bawah KKM.

d. Memperhatikan yang Lebih

Memberikan perhatian yang lebih kepada siswa adalah sala satu upaya yang penting dalam perkembangan siswa, namun demikian siswa yang mendapatkan nilai dibawa KKM, keaktifan siswa tergantung dari perhatian yang diberikan oleh orang tua maupun guru.

Guru dapat perperang penting dalam proses remedial, sebelum siswa melaksanakan remedial, guru memberikan perhatian yang lebih kepada siswa karna siswa yang mendapatkan nilai di bawah KKM minat untuk belajarnya berkurang namun demikian guru sangat penting dalam perkembangan siswa dalam lingkungan sekolah.

Peneliti melakukan wawancara lapangan dengan guru bahwa dalam membangun semangat belajar siswa yang minat belajarnya berkurang dengan memberikan perhatian yang lebih dapat disimak melalui ungkapan dari guru pada hari rabu 28/03/2018 adalah sebagai berikut.

"Saya sebagai guru yang sangat perhatian kepada siswa dengan banyak nilai yang belum tuntas, dengan nila-nilai siswa yang belum mencapai KKM yang telah di tentukan adalah 75 dengan demikian saya memberikan perhatian yang lebih dari teman-teman yang sudah mencapai KKM"

Hasil wawancara di atas megambarkan bahwa guru memberikan perhatian yang lebih kepada siswa yang belum mencapai KKM dengan demikian akan mempengaruhi motivasi belajar siswa yang belum mencapai KKM, sebelum berjalanya proses remedial guru sudah melaksnakan upaya sebelum remedial dapat di perkuar dengan hasil observasi lapangan bahwa dengan memberikan perhatian yang lebih kepada siswa yang belum mencapai KKM.

Kesimpulan dari hasil wawancara, dokumentasi, dan observasi lapangan bahwa upaya-upaya yang dilakukan oleh guru sudah baik dengan demikian siswa yang mendapatkan nilai di bawah KKM semakin berkurang, upaya guru PPKn dalan melakukan proses remedial untuk mencapai KKM kelas VIII B SMP Negeri 3 Dompu, di dalam proses remedial guru melakukan upaya-upaya untuk memajukan semangat siswa yang belum mencapai KKM yang ditetapkan oleh guru.

\section{Faktor Yang Mempengaruhi Upaya Guru PPKn Dalan Melakukan Remedial Untuk Mencapai KKM kelas VIII B SMP Negeri 3 Dompu}

Untuk memperoleh mengenai faktor yang mempengaruhi upaya guru dalam proses remedial, peneliti melakukan wawancara dengan guru dan siswa apakah adanya faktor-faktor internal ataupun eksternal sehingah guru melakukan upayaupaya dalam proses remedial berjalan.

Hasil observasi, wawancara, dan dokumentasi bahwa berjalanya proses remedial karna masih banyak siswa yang belum mencapai KKM, dengan demikian guru sangat berperang penting didalam perkembangan anak yang nilainya masih belum mencapai KKM.

Siswa yang belum mencapai KKM guru harus mengetahui faktor-faktor apa saja yang dapat mempengaruhi nilai siswa, dengan demikian guru memberikan beberapa upaya yang harus dilakukanya, pada umumnya guru memberikan yang terbaik untuk minat belajar supaya siswa mampu mencapai KKM.

Peneliti melakukan wawancara di lapangan dengan guru apa faktor-faktor yang dapat mempengaruhi upaya guru dalam pelaksanaan remedial pada tanggal 5/04/2018 adalah sebagai berikut.

"Dalam pelaksanaan remidial tidak begitu saja berjalan dengan lancar, ada hambatan dalam pelaksanaannya. Faktor internal dan faktor eksternal dalam proses remidial pada mata pelajaran PKKn di SMP Negeri 3 Dompu adalah kurangnya waktu untuk melaksanakan remidial, kurangnya ruangan untuk melaksanakan remidial, serta adanya kegiatan lain yang menunda terlaksananya remedial"

Hasil wawancara di atas mengambarkan bahwa faktor internal dan eksternal dalam proses remedial sangat berpengaruh, Oleh karena itu remidial dilaksanakan sebagaimana mestinya, remidial yang dilaksanakan di sekolah hanya dalam bentuk pengadaan ulangan kembali yang diberikan kepada siswa, kemudian siswa mengerjakan lagi, dimana hasil akhirnya jika lebih baik akan meningkatkan ketuntasan belajar siswa.

Adanya faktor internal dan faktor eksternal dapat mempengaruhi upaya guru memberikan remedial kepada siswa yang belum mencapai KKM, dengan adanya faktor-faktor guru mampu mengetahui apa penyebab siswa yang tidak mencapai KKM adalah sebagai berikut :

\section{a. Faktor Internal}

Pelaksanakan proses remedial akan berjalan dengan lancar namun demikian guru harus mempersiapkan diri lebih matang untuk memberikan yang lebih baik untuk siswa, dan proses remedial tidak akan berjalan dengan lancar jika banyak hambatan-hambatan sebelum melakukan remedial seperti kurangnya efektif waktu guru ataupun gurunya malas bisa juga tergantung dari siswa seperti siswa yang belum mencapai KKM tidak mau mengikuti remedial dan banyak faktor-faktor lainnya.

Terlaksananya proses remedial karna masih banyak siswa yang mendapatkan nilai di bawah 
KKM karna pada dassarnya guru menetapkan standar KKM adalah 75, dengan nilainya belum mencapai standa siswa harus mengikuti remedial dan banyak juga siswa yang tidak mengikuti remedial.

Hasil wawancara lapangan dengan guru bahwa faktor yang mempengaruhi upaya guru dalam melakukan remedial dapat disimak pada hari Rabu tanggal 5/04/2018 sebagai berikut:

"Faktor yang mempengaruhi upaya guru dalam meningkatkan nilai siswa disini dapat kami tuturkan bahwa dibutuhkan faktor internal yang dimaksud disini adalah fakto-faktor yang keberadaanya turut mendukung dalam meningkatkan nilai siswa seperti kesiapan siswa dan kesiapan guru tampa adanya kesiapan guru dan siswa maka kegiatan remedial dalam meningkatkan nilai siswa tidak akan berjalan dengan baik, faktor internal yang di maksud saya adalah kurangnya persiapan guru, siswa yang tidak mau remedial"

Hasil wawancara lapangan di atas mengambarkan bahwa dalam proses remedial yang di programkan oleh guru sangat penting dalam peningkatan nilai siswasupaya dapat membangun motivasi dalam dirinya dengan mendapatkan nilai di bawah KKM. dilihat dari hasil obeservasi lapangan dan dokumentasi bahwa Guru dapat menciptakan suasana remedial lebih baik karna dari kesiapan guru yang disampaikan oleh guru.

Kesiapan guru dengan siswa dalam proses remedial baik di dalam kelas maupun diluar kelas dapat mempengaruhi hambatan dalam terlaksananya proses remedial, adanya remedial karna siswa masih banyak yang belum mencapai KKM namun guru selalu berusaha supaya siswa semakin berkurang untuk mendapatkan nilai di bawah KKM.

Faktor internal yang dilakukan oleh guru dalam proses remedial untuk mencapai KKM adalah :

1) Kurangnya persiapan guru

Guru merupakan panutan serta sebagai orang tua yang harus mengayomi dan mengasu siswasiswanya yang berada dalam lingkungan formal, tugas utama guru adalah mendidik,mengajar membimbing, melatih dan mengevaluasi peserta didik di jalur pendidikan formal.

Hasil observasi lapangan peneliti dari banyak tugas utama guru hanya beberapa saja yang dijalankan tugasnya, guru harus menampakan terjadinya perubahan siswa, terjadinya remedial karna masih banyak siswa yang belum mencapai KKM yang telah ditetapkan maka guru selalu mengupayakan untuk merubah siswa menjadi siswa yang selalu efektif, dengan efektifnya siswa maka mampu mencapai KKM.
Guru yang kurangnya kesiapan dalam proses remedial maka akan terjadinya hambatan dalam remedial, jika waktu tidak berjalan efektif yyang ditetapkan oleh guru sesuai dengan rencana maka terjadinya remedial akan terbengkalai karna waktu tidak mendukung.

Peneliti melaksana wawancara dengan guru di SMP Negeri 3 Dompu pada hari rabu 5/04/2018 dapat disimak di bawah ini.

"kurang efektif waktu yang saya tentukan memang akan mempengaruhi terjadinya proses remedial akan keterbengkalai, jika terjadinya proses remedial dengan waktu yang tepat maka proses remedial akan berjalan dengan lancar"

Hasil wawancara lapangan di atas mengambarkan bahwa kurangnya efektif waktu maka dapat mempengaruhi terjadinya proses remedial, proses remedial akan menjadi terbengkalai jika waktunya tidak efektif yang telah ditentukan oleh guru, guru mengupayakan agar proses remedial akan berjalan dengan lancar.

2) Siswa Yang Tidak Ikut Program Remedial

Proses remedial tidak akan berjalan dengan lancar jika masih banyak Siswa yang tidak mau ikut remedial dan akan mempengaruhi proses remedial tidak berjalan dengan lancar, remedial dilaksanakan karna masih banyak siswa yang mendapatkan di bawah KKM namun demikian siswa tidak ada kemauan untuk memperbaiki.

Siswa yang ingin memperbaiki nilai akan mempunyai keinginan untuk remedial walaupun ada sebagian siswa yang tidak ingin memperbaiki nilai karna tidak ada kemauan dalam dirinya, dapat diperjelas dari ungkapan dari guru bahwa siswa tidak mau mengikuti program remedial pada hari Rabu 5/04/2018

"perlu diketahui bahwa program remedial diberikan kepada siswa yang telah menuntaskan materi berdasarkan KKM, remedial diberikan kepada siswa agar dapat mencapai KKM sedangakn siswa tidak ada keinginan untuk mengikuti remedial, ketika materi dilanjutkan maka siswa yang mengikuti program remedial dapat berjalan bersama dengan siswa yang telah mencapai nilai KKM. Pengayaan tidak diberikan jika tidak ada siswa yang mengikuti program remedial, artinya semua siswa dalam satu kelas telah menuntaskan materi berdasarkan KKM.

Hasil wawancara di atas mengambarkan bahwa program remedial diberikan kepada siswa yang belum mencapai KKM, remedial dilaksanakan jika dari 50\% yang belum mencapai KKM tetapi sebagian siswa yang belum mencapai KKM tidak ada keinginan untuk mengikuti remedial.

Hasil wawancara, dokumentasi dan observasi bahwa faktor internal berada dalam siswa maupun guru, faktor internal terdiri dari siswa yang tidak 
mau mengikuti remedial dan kurangnya kesiapan guru di dalam teelaksananya remedial. Proses remedial tidak akan berjalan dengan lancer jika tidak saling melengkapi antara guru dengan siswa.

\section{b. Faktor Eksternal}

Faktor eksternal yang dapat mempengaruhi proses terjadinya remedial, terlaksananya remedial pasti ada faktor-faktor yang dapat menggangu terjadinya remedial seperti faktor keluarga dan faktor lingkungan. Dengan demikian faktor-faktor tersebut akan memberikan dampak baik itu dampak positif dan dampak negatif untuk perkembangan prestasi belajar siswa.

Hasil observasi lapangan bahwa masih banyak siswa yang mengalami kurangnya perhatian dari orang tua maupun di lingkungan sekitar, disini guru harus memberikan upaya-upaya untuk meningkatkan hasil belajar siswa seperti guru melakukan dengan cara memberiakan motivasi, perhatian yang lebih sehinggah siswa mampu membangun semangat dalam mengikuti program perbaikan yang dilakukan oleh guru.

Peneliti melakukan wawancara di lapangan dengan guru bahwa Faktor yang mempengaruhi upaya guru PPKn dalam proses remedial untuk mencapai KKM dapat disimak melalui kutipan pada hari rabu 5/04/2018 sebagai berikut:

"Saya selaku guru PPKn sudah berupaya semaksimal mungkin dalam mendidik siswa, dalam proses remedial berlangsung masih ada siswa yang keluar masuk kelas tetapi tidak semua siswa selalu bersikap baik di dalam kelas maupun di luar kelas. Dari ada beberapa faktor saya temukan baik itu di sekitar lingkungan maupun keluarga dan proses remedial dilaksanakan karena siswa masih banyak yang belum mencapai KKM"

Hasil wawancara lapangan di atas mengambarkan bahwa masih banyak siswa yang tidak mau mengikuti remedial karna pengaruh dari faktor keluarga maupun lingkungan dapat memberikan dampak terhadap perkembangan peserta didik, tetapi guru selalu melakukan upayaupaya sebelum terlaksannya proses remedial supaya siswa semangat mengikuti remedial, dan dapat diperkuat dengan hasil observasi lapangan yang dilakukan oleh peneliti bahwa faktor keluarga dan lingkungan sangat memberikan dampak kepada siswa yang masih di bawah umur.

a.) Faktor keluarga

Di dalam lingkungan keluarga siswa harus di perhatikan dalam kegiatan yang dilakukanya, karna peserta didik sangat membutuhkan perhatian orang tua, dengan adanya perhatian dan dorongan dari orang tua maka peserta didik akan lebih giat untuk belajar, orang tua sangat penting dalam perkembanga siswa.

Siswa yang kurang perhatian dari orang tua maka berbeda tingka laku dengan siswa yang mendapatkan perhatian yang lebih, orang tua adalah faktor utama di dalam lingkungan keluarga. peneliti melakukan wawancara lapangan dengan salah satu siswa yang bernama Al kelas VIII B, ia adalah seorang siswa yang sangat mendapatkan nilai di bawah KKM pada hari rabu 5/04/2018 adalah sebagai berikut.

"saya adalah salah satu siswa yang sangat nakal dan minat belajar saya kurang, saya jarang kesekolah karna kurang perhatian dari orang tua, kedua orag tua saya sudah pergi TKI dan TKW di luar negeri"

Selain Al peneliti juga melakukan wawancara di lapangan dengan siswa yang bernama Mukmin ia mendapatkan nilai di atas KKM yang telah di tetapkan oleh guru, Mukmin mendapatkan perhatian yang lebih dari orang tua, dapat di perjelas hasil wawancar dapat disimak melalui ungkapan mukmin di bawah ini.

"saya semangat belajarnya sangat maju karna perhatian yang lebih dari kedua orang tua dan dalam lingkungan keluarga, setiap ulangan yang mendapatkan dilai di atas KKM"

Hasil wawancara peneliti dengan saudara $\mathrm{Al}$ dan Mukmin di atas mengambarkan bahwa di setiap individu memiliki perhatian yang berbeda, guru selalu selalu melakukan upaya dalam meningkatkan hasil belajar siswa, upaya guru sudah cukup baik dalam mendorong siswa tetapi kurang dorongan dari orang tua karna bukan dari guru saja untuk mendorong minat belajar siswa melainkan dorongan dari orang tua yang lebih penting.

\section{b.) Faktor lingkungan}

Didalam lingkungan pergaulan siswa sangat berpengaruh ke dampat yang negatif dan positif karna tergantung dari teman bermain, karna faktor lingkungan sangat berpengaruh untuk anak yang masih menempuh

Faktor yang mempengaruhi upaya guru dalam melaksanakan proses remedial untuk mencapai KKM. Dari ungkapan bapak Irwan pada hari rabu 5/04/2018 sebagai berikut.

"faktor lingkungan dapat mempengaruhi terhadap prestasi belajar siswa, karna sebagian waktu siswa berada dan bergaul di lingkungan baik itu lingkungan keluarga, sekolah, dan lingkungan masyarakat. Dari ketiga lingkungan ini akan memiliki nilai prestasi belajar yang tidak ketergantungan ada dampak positif dan dampak negatif.

Menurut bapak Irwan dari beberapa faktor di atas, yang mempunyai pengaruh lingkungan dalam meningkatkan nilai siswa supaya dapat mempengaruhi siswa yang melaksanakan remedial, adanya proses remedial karna masih banyak siswa yang belum mencapai KKM, guru berusaha mengurangi proses remedial yang mendapatkan di 
bawah KKM. Guru juga berusaha memberikan metode dan strategi yang mudah dipahami supaya siswa mudah mengerti.

Kesimpulan hasil wawancara, dokumentasi dan observasi bahwa faktor eksernal ada di dalam lingkungan dan keluarga, adanya faktor-faktor tersebut dapat mempengaruhi perkembangan siswa dan dapat mempengaruhi minat belajar siswa.

Kesimpulan dari faktor internal dan eksternal dapat membangun dan memperhambat perkembangan siswa, di dalam perkembangan siswa sangat penting dan dapat mempengaruhi perkembangan siswa yang masih di bawah umur karna dalam faktor internal berada dalam siswa maupun guru, faktor internal terdiri dari siswa yang tidak mau mengikuti remedial dan kurangnya kesiapan guru di dalam terlaksananya remedial. proses remedial tidak akan berjalan dengan lancar jika tidak saling melengkapi antara guru dengan siswa. dan faktor eksernal ada di dalam keluarga dan lingkungan, adanya faktor-faktor tersebut dapat mempengaruhi perkembangan siswa dan dapat mempengaruhi minat belajar siswa.

\section{TEMUAN DAN DISKUSI}

Proses remedial ini biasanya diberikan kepada siswa yang belum mencapai KKM, remedial merupakan penyembuhan yang di berikan kepada siswa yang tidak memenuhi standar dan siswa mampu memahami instrumen soal, dalam proses remedial guru memberikan soal-soal susuai dengan kompetesi dasar yang di pelajari dan mudah dipahami supaya siswa mampu mencapai standar KKM yang ditetapkan. Bahwa apa yang dilakukan oleh guru bersependapat dengan pernyataan bahwa remedial adalah suatu tindakan atau proses penyembuhan/peremedian atau penanggulangan ketidak mampuan atau masalah-masalah pembelajaran[14]. Program remedial merupakan sarana yang diperlukan agar peserta didik mampu mencapai target Kriteria Ketuntasan Minimal (KKM) yang telah ditetapkan pada mata pelajaran PPKn.

Pelaksanaan remedial ada beberapa tindakan yang harus dilakukan oleh guru diantaranya pelaksanaan diagnosis kesulitan belajar, penelaahan kembali kasus, pemilihan alternatif tindakan, pemberian layanan khusus dan menyusun program remedial itu sendiri. Prosedur pelaksanaan diagnosis kesulitan belajar terdiri dari identifikasi siswa yang diperkirakan mengalami kesulitan belajar, melokalisasi letak kesulitan belajar, memperkirakan alternatif bantuan, menetapkan kemungkinan cara mengatasinya dan tindak lanjut[15].

Metode pembelajaran merupakan salah satu komponen dalam belajar mengajar, suatu alat untuk mencapai tujuan dengan dukungan alat bantu mengajar, dan merupakan kebutuhan dalam sistem pendidikan, sehingga perlu adanya penentuan metode yang akan digunakan dalam pelaksanaan pembelajaran. Dalam pemilihan metode guru harus mempertimbangkan tujuan pembelajaran, bahan pembelajaran, guru, siswa dan situasi pembelajarannya. Metode yang dilaksanakan dalam proses remedialmerupakan keseluruhan kegiatan bimbingan kesulitan belajar mulai dari langkah indentifikasi kasus sampai dengan langkah tindak lanjut,[15] metode-metode yang dapat digunakan dalam pelaksanaan remedialyaitu, pemberian tugas, diskusi, tanya jawab, kerja kelompok, tutor sebaya dan pengajaran individual. Metode yang akan digunakan harus ditetapkan terlebih dahulu sesuai dengan jenis, sifat, dan latar belakang kesulitan belajar yang dialami siswa. Selain itu juga dapat digunakan untuk mengenali kasus siswa yang berkesulitan belajar.

Upaya yang dilakukan oleh guru dalam melaksanakan proses remedial untuk mencapai KKM yaitu dengan memberikan motivasi dan memberikan dukungan kepada siswa. dengan memberikan perhatian yang lebih kepada siswa supaya saat remedial siswa mampu mencapai KKM yang ditetapkan oleh guru, sebelum melaksanakan remedial guru memberikan bimbingan sebelum kepada siswa sebelum berjalanya proses remedial.

Guru harus sadar bahwa siswa yang mendapatkan di bawah KKM karna kurangnya motivasi, dukungan maupun umpan balik. Ini bermakna siswa tidak mempunyai keinginan untuk belajar, disinilah guru berperang dalam membangun minat belajar siswa dalam memberikan motivasi dalam lingkunga sekolah. juga bertingkah laku akan memberikan pengaruh secara tidak langsung kepada siswa. Guru harus menerima hakikat bahwa nilai siswa sudah tertanam dalam diri siswa sehinggah siswa mampukah belajar dengan sunguhsunguh. Guru haruslah bersedia untuk mengajar dengan mengambil kira pengetahuan dan pembelajaran. Guru dikehendaki mengembangkan nilai siswa yang belum mencapai KKM ini dan membimbing mereka semasa pengajaran dilaksanakan. Pendidikan di sekolah digunakan untuk meningkatkan pengetahuan siswa ke arah mencapai kesuksesan kurikulum untuk melahirkan individu yang cerdas.

Hasil observasi wawancara dan dokumentasi Bahwa upaya guru di SMP Negeri 3 Dompu sudah sangat baik meskipun masih memiliki beberapa kendala. Guru akan selalu berusaha untuk bagaimana meningkatkan nilai dan membangun motivasi belajar siswa yang mendapatkan nilai di bawah KKM, guru berusaha untuk menciptakan anak bangsa yang cerdas.

Melaksanakan proses remedial harus ada yang namanya faktor internal dan faktor eksternal yang ada di SMP Negeri 3 Dompu, guru melakukan remedial harus ada dukungan dari siswa supaya dalam proses remedial berjalan dengan lancar, guru dengan siswa harus selalu bekerja sama untuk menciptakan suasana yang damai dalam terlaksanannya remedial.

Faktor yang mempengaruhi upaya guru dalam meningkatkan nilai siswa disini dapat kami tuturkan bahwa dibutuhkan faktor internal dimaksud disini adalah fakto-faktor yang keberadaanya turut mendukung dalam meningkatkan nilai siswa yang mendapatkan di bawah 
KKM. Tampa adanya kesiapan guru dan siswa proses remedial tidak akan berjalan dengan baik.

Adanya faktor internal dan eksternal yang dapat mempengaruhi proses terjadinya remedial, terlaksananya remedial pasti ada faktor-faktor penghambat yang dapat menggangu terjadinya remedial

Faktor yang mempengaruhi upaya guru PPKn dalam proses remedial untuk mencapai KKM dapat berupaya semaksimal mungkin dalam mendidik siswa akan tetapi upaya yang guru lakukan memiliki faktor seperti dalam proses pembelajaran berlangsung masih ada siswa yang keluar masuk kelas, ribut, dan bolos. Karena tidak semua siswa selalu bersikap baik di dalam kelas maupun di luar kelas. Dari ada beberapa faktor saya juga berusaha memberiakan yang terbaik dan metode yang sangat bervariasi sehinggah siswa dalam belajar mampu mehami, proses remedial dilaksanakan karena siswa masih banyak yang belum mencapai KKM"

Faktor internal meliputi kurangnya efektif waktu guru dan siswa tidak mau mengikuti program remedial,adanya faktor internal sebagai penghambat dalam proses remedial maka guru melakukan upayaupaya sebelum terjadinya proses remedial,

Sedangkan faktor eksternal yang dapat berpengaruh di luar kepribadian siswa seperti pengaruh lingkungan dan keluarga dengan adanya faktor intenal dan faktor eksternal sependapan dengan. Ada dua faktor yang mempengaruhi keberhasilan siswa dalam belajar yaitu: faktor internal dan faktor eksternal[16]. Faktor eksternal adalah faktor yang berada di luar individu, lingkungan keluarga, sekolah dan masyarakat,sedangkan faktor internal yaitu tuga tahap bagian yaitu faktor kelelahan (kelelahan jasmani maupun rohani) faktor jasmani (kesehatan, cacat tubuh) dan faktor psikologis (intelegensi, perhatian, minat, bakat, keterampilan dan kesiapan bealajar). Kesiapan merupakan faktor penting penentuan keberhasilan belajar, kesiapan ini perlu diperhatikan dalam proses belajar, karena jika siswa belajar sudah ada kesiapan, maka prestasi belajar akan lebih baik.

Upaya guru dalam meningkatkan hasil belajar siswa itu sudah cukup baik melaingkan kurang dorongan dari orang tua karna bukan dari guru saja untuk mendorong minat belajar siswa melainkan dorongan dari orang tua. Didalam lingkungan pergaulan siswa sangat berpengaruh ke dampat yang negatif dan positif karna tergantung dari teman bermain, karna faktor dari lingkungan sangat berpengaruh untuk anak di bawah Umur. Faktor yang mempengaruhi upaya guru dalam melaksanakan proses remedial untuk mencapai KKM.

Beberapa faktor di atas mengambarkan bahwa faktor internal dan eksternal ada memberikan dampak positif dan dampak negatif. adanya proses remedial karna masih banyak siswa yang belum mencapai KKM, guru berusaha mengurangi proses remedial yang mendapatkan di bawah KKM. Guru juga berusaha memberikan metode dan strategi yang mudah dipahami supaya siswa mudah mengerti dan mampu mencapai KKM.
Beberapa faktor masih banyak siswa yang mengalami hambatan karna dari beberapa faktor, guru mampu membangun motivasi yang dihadapi siswa karna dalam suatu remedial pasti ada yang namanya kesulitan yang dihadapi siswa, sebelum melakukan proses remedial guru memberikan kisis-kisi soal yang muda dipahami oleh siswa.

\section{E. SIMPULAN DAN SARAN}

Penerapan remidial sebagai usaha meningkatkan ketuntasan belajar siswa dalam mata pelajaran PPKn di SMP Negeri 3 Dompu mampu dilaksanakan dengan lancar. Hasil ketuntasan belajar yang dicapai siswa dalam mata pelajaran PPKn setelah mengikuti proses remidial di SMP Negeri 3 Dompu dapat berubah nilai siswa, dan bentuk perubahan tingkah laku belajar siswa setelah mengikuti remidial. Upaya guru dalam proses remedial untuk mencapai KKM dan faktorfaktor yang mempengaruhi upaya guru dalam proses remedial untuk mencapai KKM. Sudah di laksanakan dengan baik.

Upaya yang dilakukan oleh guru sudah baik dengan demikian siswa yang mendapatkan nilai di bawah KKM semakin berkurang, upaya guru PPKn dalan melakukan proses remedial untuk mencapai KKM kelas VIII B SMP Negeri 3 Dompu, di dalam proses remedial guru melakukan upaya-upaya untuk memajukan semangat siswa yang belum mencapai KKM yang ditetapkan oleh guru seperti memberikan motivasi, perhatian yang lebih dan pemberian umpan balik.

Faktor internal dan eksternal dapat membangun dan memperhambat perkembangan siswa, di dalam perkembangan siswa sangat penting dan dapat mempengaruhi perkembangan siswa yang masih di bawah umur karna dalam faktor internal berada dalam siswa maupun guru, faktor internal terdiri dari siswa yang tidak mau mengikuti remedial dan kurangnya kesiapan guru di dalam terlaksananya remedial. proses remedial tidak akan berjalan dengan lancar jika tidak saling melengkapi antara guru dengan siswa. dan faktor eksernal ada di dalam keluarga dan lingkungan, adanya faktorfaktor tersebut dapat mempengaruhi perkembangan siswa dan dapat mempengaruhi minat belajar siswa.

Sebelum mengadakan remidial guru sebaiknya melakukan analisis soal sehingga guru mengetahui kekurangan siswa, perbedaan tingkat kesulitan belajar siswa, kemudian guru mengetahui pendekatan apa yang akan dipakai guru. Guru sebaiknya melakukan pendekatan secara individual serta diharapkan mempunyai sifat telaten dalam pembinaan terhadap siswa untuk meningkatkan ketuntasan belajar siswa. Guru juga mau menyediakan waktu luang untuk siswa dalam pelaksanaan remidial yang disesuaikan dengan 
prosedur, sehingga siswa dapat memahami materi yang disampaikan.

\section{UCAPAN TERIMA KASIH}

Penulis mengucapkan terima kasih kepada Pihak Universitas Muhammadiyah Mataram yang senantiasa menyumbangkan dana, memberikan saran dan masukan kepada penulis sehingga artikel ilimiah ini selesai dengan baik.

\section{DAFTAR RUJUKAN}

[1] S. Saddam, D. L. Setyowati, and J. Juhadi, "Integrasi Nilai-nilai Konservasi dalam Habituasi Kampus untuk Pembentukan Kepribadian Mahasiswa Universitas Negeri Semarang," $J$. Educ. Soc. Stud., vol. 5, no. 2, pp. 128-135, 2016.

[2] D. T. Kependidikan, D. JENDERAL, P. M. P. D. A. N. T. KEPENDIDIKAN, and D. P. NASIONAL, "Kriteria dan Indikator Keberhasilan Pembelajaran.” Jakarta: Direktur Tenaga Kependidikan Ditjen PMPTK, 2008.

[3] H. Hafid, K. Kartono, and S. Suhito, "Remedial Teaching untuk Mengatasi Kesulitan Belajar Siswa pada Kemampuan Pemecahan Masalah Matematika berdasarkan Prosedur Newman," Unnes J. Math. Educ., vol. 5, no. 3, pp. 257-265, 2016.

[4] W. Chrisnajanti, "Pengaruh Program Remedial terhadap Ketuntasan Belajar Siswa," J. Pendidik. Penabur, vol. 1, no. 1, pp. 81-86, 2002.

[5] D. Mardapi, S. Hadi, and H. Retnawati, "Menentukan Kriteria Ketuntasan Minimal (KKM) Berbasis Peserta Didik Mata pelajaran Matematika SMP di Kota Yogyakarta.” Prosiding, 2014.

[6] W. Wirmawati, "Penerapan Pembelajaran Remedial Dalam Upaya Mencapai Ketuntasan Belajar Siswa Pada Mata Pelajaran PKn Kelas VIIIA SMP Negeri 1 Sindue," EDU Civ., vol. 3, no. $2,2015$.

[7] P. Sugiyono, Metode Penelitian Kuantitatif, Kualitatif, dan R\&D. 2013.

[8] A. Muhammad, "Guru dalam proses belajar mengajar," Bandung Sinar Baru Algensindo, 2002.

[9] S. Nasution, Berbagai pendekatan dalam proses belajar dan mengajar. PT. Bina Aksara, 2000.

[10] D. Abdurrahman, Metodologi Penelitian Sejarah Islam. Penerbit Ombak, 2011.

[11] K. G. Esterberg, "Qualitative methods in social research," 2002.

[12] S. Hadi, "Metodologi research jilid I," Yogyakarta Andi, vol. 94, p. 95, 2004.

[13] M. B. Milles, "Huberman. 1984. Qualitative Data Analysis." London: Sage Publication.

[14] R. Hildayani, M. Sugianto, R. Tarigan, and E. Handayani, "Psikologi perkembangan anak," 2014.

[15] K. N. F. Sugihartono, F. Harahap, F. A. Setiawati, and S. R. Nurhayati, "Psikologi Pendidikan," Yogyakarta UNY, 2007.

[16] B. Slameto, "Faktor-faktor yang mempengaruhi," Jakarta: Rineka Cipta, 2010. 